DOI https://doi.org/10.30525/978-9934-26-004-9-109

\title{
ГУМАНІСТИЧНИЙ ПОТЕНЦІАЛ ДИЗАЙНУ В КУЛЬТУРОЛОГІЧНОМУ ДИСКУРСІ
}

\author{
Лагода О. М. \\ доктор мистеитвознавства, доцент, \\ професор кафедри дизайну тканин і одягу \\ Харківської державної академії дизайну і мистеитв \\ м. Харків, Украӥна
}

Переважна більшість сучасних досліджень дизайну доводить доцільність застосування культурологічного підходу. Історія становлення дизайну, як специфічної сфери творчості та професійної діяльності, насамперед, демонструє втілення досягнень науковотехнічного прогресу, але й актуалізує соціокультурний аспект в контексті його впливу на життєдіяльність людини в цілому. У цьому, як відзначав В. Даниленко, виявляється «двоїста природа» дизайну, який, прагнучи «інтернаціонального вигляду», «намагається творити й у річищі пошуків власної ідентичності окремих націй, відтворюючи у своєму продукті унікальність» [1, с. 17].

Як художньо-проєктна практика, дизайн грунтується на ідеї свідомого перетворення та удосконалення людиною середовища власного побутування та речей, які його наповнюють, що вимагає осмислення різних форм інформації - вербальної, візуальної, сенсорної, ін. Наприклад, суголосність форми i функцій, виражена предмено, домінувала в дизайні 1920-1950-х років. У 1960-1970-х - значимості набуло середовище як комплекс предметно-просторових рішень, обумовлених таким поняттям як «спосіб життя». Зростання ж ролі споживчих запитів призвело до комерціалізації дизайну 1980-х років. 3 1990-х - дизайн зазнає «гуманітаризації середовища як гармонізації сфери проживання людини, що має відповідати високим критеріям якості людського життя» [2, с. 183]. Очевидно, предметне середовище активно впливає на свідомість людей і здатне змінювати їх ціннісні установки. Отже, дизайн є одним з найважливіших чинників творення сенсу та образу життя сучасного суспільства [3].

Значимість культурології як гуманітарної науки, здатної забезпечити цілісне підгрунтя для осмислення дизайн-процесу і дизайн-продукту, стати методологічною основою теорії та практики дизайну, обгрунтовує 
Т. Бистрова. I мова, насамперед, про застосування культурологічних концептів. У своїй публікації науковець аналізує переваги і вади застосування культурологічного підходу в сучасних дослідженнях дизайну та наводить ряд вдалих прикладів реалізованих проєктів. «Дизайн... може бути переміщеним 3 предметного поля мистецтвознавства в бік культурології, яка тлумачиться як особливий тип мислення щодо феноменів і артефактів культури, які репрезентують інформацію про свого творця та носія» - зазначає вона [4, с. 7]. Натомість, відмова від аналізу дизайн-продуктів поза контекстом культури «для теорії дизайну..., по великому рахунку, означає стагнацію, оскільки не наближає... ні до аналізу проєктного мислення, ні до розуміння соціокультурної специфіки продукту» [4, с. 7]. Т. Бистрова переконує, що для аналізу більшості дизайн-аспектів $\epsilon$ достатньо моментів, які пов'язують дизайн і культурологічний дискурс. В сучасних умовах зорієнтованість дизайну на різні критерії технічної та функціональної досконалості елементів матеріальної культури поступилася місцем осмисленню дизайну через призму різних параметрів культури як цілісності. Відтак, естетична організація предметно-просторового середовища, підпорядкованість дизайну законам i принципам естетичного формотворення виявляють його глибинні зв'язки 3 духовними і художніми складниками культури в цілому, тобто - позиціонують як явище культури. Таким чином, дизайн набуває виразного культурологічного звучання, що й обумовило, на противагу попереднім рокам, необхідність культурологічного підходу в дослідженнях дизайну.

Такі напрями розвитку дизайну XXI століття як екологічний дизайн i концепт «розумного споживання» чи «сталого розвитку»; психодизайн $\mathrm{i}$ розвиток перцептивної культури, тобто особистісної культури людини і властивої їй естетики, грунтуються на гуманістичних цінностях. Дизайн, що є гуманістично-орієнтованим, має за мету протидіяти таким способам задоволення людських потреб, як стандартизація та уніфікація, які роками формують суспільні запити на естетичні смаки, ідеали і цінності. Естетичні чинники визначають органічну єдність людини 3 довкіллям, гармонізують процеси перетворення навколишнього предметного середовища, утворюючи своєрідний «етичний поворот», дотичний до домінування естетично представленої практичної функції дизайнпродуктів. Відтак, екологічність та етичність для дизайнерів - це надважливі позиції, які утілюються в об'єктах, що поза часом, i формують етику суспільних відносин в соціокультурному дискурсі. Дизайну, як цілісній системі діяльності, властиві важливі соціальні та 
культурні функції, тому актуалізуються та трансформуються методи i принципи дизайну, адаптивність яких унеможливлює бездумне та ганебне тиражування і перевиробництво.

Розкриття гуманістичного потенціалу дизайну постало в багатьох дослідженнях доволі ефективним, насамперед, 3 точки зору методології. Для науковців центральним питанням стало емоційно-духовне та інформаційно-комунікативне включення людини в дизайн-процес, як на етапі створення та реалізації нових форм предметів, так і в процесі їх функціонування. Це, зокрема, привернуло увагу до репрезентативних практик дизайну, які, маючи давню та цікаву історію переродження художньо-проєктної творчості, виробили специфічні механізми впливу реально і віртуально на всіх суб'єктів проєктного процесу [4].

Кореляція методології дизайн-діяльності, завдань дизайну та засобів їх реалізації посилюють суб'єктивність проектних рішень, які приймаються. А це, своєю чергою, прискорило розвиток адаптивного проєктування, в якому дизайнер, часто - віртуально, проєктує не сам продукт, а можливі ситуації його використання, для чого звертається до розробки своєрідних «сценаріїв життя» конкретних речей. Іншими словами, дизайн-процес зазнає нарації - своєрідних змістовних нашарувань. Наративність, як відомо, $\epsilon$ невід'ємною властивістю культури, яка глибоко коріниться в історії ï становлення й розвитку. В контексті ж окресленої проблематики вона може тлумачитися як нова парадигма художньо-проєктної культури, як концептуально-наративна стратегія розвитку дизайну XXI століття. Завдяки цій стратегії у дизайнерів-практиків і теоретиків з'явилися нові можливості синтезу минулого досвіду та новітніх можливостей (технологій), зокрема, у віртуальному світі концептуального проєктування.

Окреслене відкриває нові горизонти для досліджень, які дозволять не лише виявити ціннісно-змістовні домінанти соціокультурного простору. Системність подібних досліджень і розгляд дизайну як культурної практики забезпечить розвиток науково-обгрунтованої теорії дизайну на підвалинах культурологічних знань.

\section{Література:}

1. Даниленко В.Я. Зміни у світовому порядку і двоїста сутність дизайну. Традищії та новації у вищій архітектурно-художній освіті. Харків: ХДАДМ, 2003. Вип. 1-2. С. 70-76.

2. Шалінський I. Новітні напрями дослідження сучасного дизайну. Прикладна культурологія $i$ культурні практики. С. 182-187: 
веб-сайт. URL: https://www.culturology.academy/wp-content/uploads/KD5_ Shalinskyi.pdf

3. Лагода О. На «межі» дизайну: критеріальні оцінки і контури поняття «дизайн вражень» в контексті культури споживання. Науковий вісник НЛУ Украӥни: зб. наук.-техн. пращь. Львів: РВВ НЛТУ України, 2013. Вип. 23.18. С. 321-327.

4. Быстрова Т.Ю. Зачем дизайну культурология. Международный журнал исследований культуры. 4 (25). С. 5-15 : веб-сайт. URL : https://cyberleninka.ru/article/n/zachem-dizaynu-kulturologiya/viewer

5. Лагода О.М. Репрезентативні практики дизайну костюма в контексті еволюції художньо-проєктної культури : дис...док. мистецтвознавства: 17.00.07 - дизайн. Київ, КНУТД, 2020. 593 с.

DOI https://doi.org/10.30525/978-9934-26-004-9-110

\title{
NON-TRADITIONAL USE OF BOOK ILLUSTRATION IN MODERN UKRAINE
}

\author{
Oliinyk V. A. \\ Candidate of Study of Art \\ Senior Teacher at the Department of Arts \\ Kyiv University of Culture \\ Kyiv, Ukraine
}

It's no secret that the illustration in the book space, besides its direct purpose - to visualize the written content, has several secondary functions (presentation of an artist and publisher, popularization of a literary work, etc.).

In this case, it is logical and fair to further develop the multifunctionality of book illustrations, and, finally, the acquisition of a certain degree of autonomy by these pictures. We do not mean the complete autonomy of the latter, the distance from the literary plot. On the contrary, we note the exceptional affinity between the artistic and literary images, which was achieved by a talented illustrator, and thus this work received the right to become a business card of a literary work even beyond its borders.

In contrast to the Soviet era, when the tendency to use easel works as a book graphics, as well as the creation of artistic series based on literary subjects as separate artistic genre [3], now we can observe the applied usage of 